question - how to ensure satisfactory quality controls for the implementation of the "Good Laboratory Practices" scheme agreed on last year, and how the confidentiality of data is to be guaranteed.

The Good Laboratory Practices scheme represents a commonly applied definition of the standards and procedures to be used in laboratories testing new chemicals. Unfortunately mistrust has clouded the agreement. High standards cost money and governments are not convinced that everyone is abiding by the rules as strictly as they ought to be, so the October meeting will examine proposals for methods to check that the practices are properly upheld.

This will be another small step towards the programme's ultimate aim of guaranteeing that the marketing authorizations handed out nationally are acceptable elsewhere. Only by using the Good Laboratory Practices scheme can a standard dossier of data on a new chemical substance, the minimum pre-marketing data, be accepted by other national authorities.

The scheme involves, though, a free flow of allegedly valuable commercial information, and this is causing worries in the chemical industry that such information will not remain confidential. The issue is complicated by the fact that there are large differences among OECD countries in the laws relating to freedom of information. Environmentalists are equally worried that poor access to information on toxicity considered confidential by industry will violate the principle of public participation in the assessment of the hazards of chemicals to which the public are exposed.

The OECD's agreement on exactly what information is relevant to hazard assessment has disappointed both the industrial and environmentalist lobbies. The various OECD working groups have come up with a document which defines what data should not be considered confidential and which specifically excludes information such as spectroscopic data which might reveal the chemical identity of a substance before a manufacturer wishes it to be generally known. A final agreement has yet to be reached in sensitive areas such as pharmaceuticals. The United States is held to be particularly responsible for backtracking on this question as the list of nonconfidential data continues to be reduced. If too much remains confidential, hazard assessment made by industry or government will be harder to question, especially if there is consistency on marketing authorizations.

So it seems there is still considerable work to be done within OECD before guidelines are agreed on what hazards can be considered acceptable, and this may prove to be the biggest stumbling block to further international cooperation in this field.

Jasper Becker

\section{How Dr Melamed lost his degree}

In 1976, new regulations came into force in the Soviet Union governing VAK, the "Higher Attestation Committee" responsible for conferring the degrees of Candidate (PhD) and Doctor (DSc/DLitt). The full text was not published at that time (a booklet was promised for "later") but the media placed considerable stress on the fact that the new regulations demanded scrutiny of the political attitude of the postulant for the degree.

It now appears that this requirement can work retroactively. During the past year, at least seven Jewish scholars have been deprived of their degrees, for having exhibited "anti-patriotic" attitudes in applying to emigrate to Israel. A document - which claims to be a transcript of such a deprivation process - has just reached Nature, and is reproduced here in a slightly abridged form.

Vera Rich

\section{From the stenographic transcript of the Scientific Council of the Faculty of Geology of Moscow State University, 20 January 1982.}

Chairman (Professor Adonis G. Gayanov): Members of the board already know the agenda for today's session: inter alia the stripping of Vladimir Grigor'evich Melamed of his academic titles due to his anti-patriotic dealings, unworthy of a Soviet scientist.

Melamed is not present, he is ill. On 18 January, two days before this session, he notified me that he had a sickness certificate (reads DrMelamed's notification).

I feel it is particularly necessary to point out the problem of his absence for the following reason. According to paragraph 5 of the regulations of VAK on the conduct of sessions for the stripping of academic titles, the person from whom the title is to be stripped has to be present.

(After some discussion, - including pressure from the public gallery - it was decided to proceed in Melamed's absence). A.G. Lyubimov: Allow me to read the material from the special committee of the board, set up to investigate the activities of V.G. Melamed, who expressed the desire to emigrate to the state of Israel:

Melamed has been working at Moscow State University for approximately thirty years. Latterly he was in charge of one of the laboratories, and was dealing with pressure-modification of the permafrost process. He distinguished himself by his energetic attitude and was therefore admitted to the Party. In 1975, he received the degree of DSc, specializing in geophysics.

In November 1980, he submitted a request to emigrate to the state of Israel, which is known to be capitalistic and no friend of the Soviet Union. In view of the increasing severity of the international situation and all that has been stated previously, we find that the decision of Melamed is an anti-patriotic act, unworthy of a Soviet scientist.

We are of the opinion that Article 104 of the VAK on the stripping of scientific titles can be applied to him. Dated 18 December 1981. Signed by all members of the committee

Chairman: Who wants to comment? Professor Epinat'"eva: I have a question about Melamed's scientific profile. Would you please specify what he has achieved in the scientific field?

Chairman: This is not the question. We are concerned with something else, not science. We are not going to discuss the scientific work of Melamed, so this is not relevant.

Professor Dinitriev: Will the minutes of the decision of the committee be added to the documents that VAK receives from us?

Chairman: Yes.

Dimitriev: Then I want to point out an error. Melamed did not defend his doctoral thesis in 1976, as the committee says, but in 1977. And it is an ill-chosen expression to say, "and all that has been previously stated". From this one might conclude that he should be deprived of his degree, not only because of his wish to emigrate from the Soviet Union but also because he worked for Moscow State University for thirty years.

Chairman: Good, we shall correct this. Any further comments? (Silence). Good. I call on Arkadii Vasilevich Kalinin, member of the committee.

Kalinin: Today our board has a rather difficult task, which is, however, completely justified by VAK regulations. As you all know, Article 104 of the VAK regulations deals with the stripping of academic degrees due to conduct unworthy of a Soviet scientist. This includes offences such as anti-patriotism. This leaves our board one choice, to decide whether or not Melamed's offence can be interpreted as anti-patriotic or not.

According to the law, emigration is permitted for the sake of reunification of families. Melamed informed the departments which grant exit visas that this prohibits public organizations from judging Melamed's activities.

Academic titles in the Soviet Union are conferred not only on the grounds of scientific criteria. . . We consider the function of an academic title to be more important than in the capitalist world. It confers not only the right to a function, but a salary. If Melamed remained a doctor, he would continue to do things to which he no longer has a right ... His titles should be taken away from him. . .

Professor Nikitin: I should like to add something in order to show two aspects of the anti-patriotism of Melamed. First, he was a Party member for a number of years and also a propagandist. When submitting his papers applying for an exit visa, he turned his back on all his early ideas. was his intention. However, no law 
Second, he is a qualified specialist, a scientist. Now he is leaving in order to work on behalf of Israeli science, to work for our opponents, our enemies. And this is even more than anti-patriotism.

Chairman: Thank you. Does anyone else wish to speak? The case is probably completely clear and we can begin voting. J. V. Medvedkov: Permit me to say something, not everything has been said. I am especially qualified to speak. Before I became involved in soil-sciences, I studied law.

It is, as you know, not only a moral judgement or the opinion of colleagues if Melamed is stripped of his academic titles ... they give a right to a scientific function, a salary, the possibility of scientific work appropriate to his academic level, admission to libraries etc.

A case like this is treated completely unambiguously by a special juridical act. I mean the Final Act of the Helsinki Accords of 1975. I should like to quote from Izvestiya, 2 August 1975.

The submission of an application for reunification of family shall not lead to changes in the rights and duties of the person who made the request or of members of his family.

Hence it is inadmissible that the board should seek to limit Melamed's rights because of his wish for reunion with members of his family in Israel.

I have not heard any proof that Melamed's conduct constitutes an antipatriotic offence.

It is no accident that in such a complete work of reference as the Soviet Encyclopaedic Dictionary (Moscow, 1979) the term "anti-patriotic" does not occur. One can use an expression which comes close to it, namely "anti-Sovietism". This term does occur in the Soviet Encyclopaedic Dictionary. On pages 63-64 it says that anti-Sovietism is an attempt to defame and misrepresent everything that the Soviet Union has achieved in economic, political and cultural fields.

When it is stated that Melamed's conduct is anti-patriotic, then he is apparently also accused of anti-Sovietism.

By whom and where has it been proved that Melamed has done anything to misrepresent and run down those things which the Soviet Union has achieved?

His application to emigrate was submitted without any publicity. It is an act which falls within existing laws and standards. He did not give public announcements and did not publish books which misrepresent and run down all that the Soviet Union has achieved.

I fear that in fact, the Soviet Union will be harmed by those people who have applied to the board with the demand that Melamed be punished.

Chairman: Any further comments?

Mrs F. Melamed: My husband is ill at the moment and I do not understand how it is possible for his case to be considered in absentia ... Today a matter is being discussed that is of vital importance to him. His entire 30 years career in the service of Soviet science has been put in doubt. Can one call such a career unpatriotic?

Why do members of the board disregard the signature of the Soviet Union below the Helsinki Final Act?

Professor Epinat"'eva: It is one thing if a worker at a normal research institute or even the Academy of Sciences expresses the wish to emigrate, but it is totally different for people working at the university to do so. The latter are dealing with young people, aren't they? The act that Melamed performed distorts the world view of our youth.

S.A. Kats: This concerns the shattering of an entire human life. And you limit yourself to two short sentences. If the matter had been dealt with by the court, the procedure would have been very different.

Professor Kalinin: I am against the fact that "anti-patriotism" and "antiSovietism" are equated. When Herzen left Russia, it was an act that we call "antiTsarism" and not "anti-patriotism".

It was the last straw to say that Melamed would be anti-Soviet. But can we call his action complimentary to the fatherland? $\mathrm{He}$ did not want to leave Moscow State University in order to make life easier for us. So we do not have to make life easier for him ... I do not think that we are in violation of the Helsinki Accords.

G.O. Marshuhuk: I myself disapprove of Melamed's action, and I told him so. But disapproving is one thing and accusing him of anti-patriotism, and punishing him severely by denying him the right to scientific work is something totally different.

I. S. Irlin: There is no doubt that Melamed behaved within the framework of the law ... During the past six to seven years, some thirty thousand people left the Soviet Union to be reunited with their families. Among them there were quite a number with doctoral or candidate's degrees. But personally I do not know of any case where one was deprived of his scientific degree. In my opinion the board wants to create a precedent.

Professor V.V. Karus: According to Article 104 of the VAK regulations, one needs three qualities to hold a scientific title: qualification, patriotism and regard for ethical standards . . . Patriotism is love for the fatherland which raised us. But Melamed decided to leave the fatherland at a time of severe international tension and for a country that propagates a malicious hostility against the Soviet Union . . . The right to work will not be taken from him, but why should he get an extra salary for working in a scientific field?

Chairman: I request you to vote for the stripping of Melamed's degree of Candidate of Physico-Mathematical Sciences. For the motion? ... Carried unanimously. I hereby declare the meeting closed.

\section{Agricultural biotechnology Soon to start}

Springtime has not induced germination of the British Technology Group's (BTG) plans for an agricultural genetics company but it is still expected to bloom this year. One snag at present seems to be the degree of scepticism among those of the calibre to be potential scientific directors about the ability of any such company to be profitable within five years, as BTG would want.

Although BTG considers the topic too sensitive to discuss, by all other accounts the plan is that the new company should have the same kind of special relationship with the UK Agricultural Research Council (ARC) as does Celltech with the Medical Research Council (MRC). Celltech was also set up by BTG (or, more precisely by the National Enterprise Board which has since fused with the National Research Development Corporation to form BTG) and operates in the field of biotechnology. Its relationship with MRC allows Celltech first refusal on any discoveries within the realms of recombinant DNA and cell hybridization that emerge from the various units of MRC. In return Cclltech channels

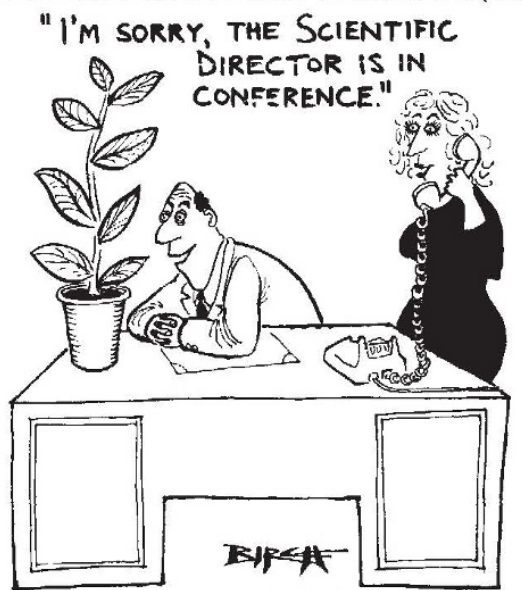

money back into MRC and has an obligation to help the council find other commercial outlets for discoveries in which it has no interest.

ARC and many of its employers who work on subjects that will be of interest to the new company (some of whom are already consultants to BTG) tend to be enthusiastic about the prospect for several reasons.

The first is the possibility of an easy and financially benefical way for ARC to channel its discoveries of commercial potential in the domain of plant breeding. At present it has no such outlet. New strains of plants developed by conventional techniques within ARC institutes have to be given to the National Seed Development Organisation which, although a profitable concern, donates its profits to the Treasury rather than directly to ARC.

For discoveries in gene cloning and transfer, that have some potential for being used in the genetic improvement of plant 